\title{
ANSWERING THE WRONG QUESTION: THE TENUOUS CASE FOR MANDATORY CORPORATE LAWS
}

\author{
Roberta Romano*
}

My comment on Jeffrey Gordon's paper is in two parts: I first suggest why this symposium, whose purpose is to define the contours of a mandatory corporation law, attempts to answer the wrong question. Thereafter, I turn to my assigned task and address directly the explanations Gordon develops for the mandatory structure of corporate law.

\section{How Binding Are "Mandatory" Corporate Laws?}

The core question for this symposium, whether and by how much state corporation laws are (or ought to be) mandatory is not, in my opinion, central to an understanding of American corporate law. For a rule to be truly mandatory, given the relative ease with which firms can reincorporate, it would have to be adopted by all of the states and the District of Columbia. More important, corporation codes are highly functional and adaptive. The rules that are identified as "mandatory" in practice have very little in common with the ordinary understanding of that term. They are either easily - and legally-side stepped, or they pose nonbinding constraints because there is no burning demand to deviate from them. ${ }^{1}$

Consider, for example, the ease with which the following provisions-ones that Gordon enumerates as illustrations of mandatory laws ${ }^{2}$ - can be circumvented:

(i) Directors must be annually elected by shareholders, or if the board is classified, which voids the annual election requirement, there is a maximum threeyear term (i.e., prohibition of a self-perpetuating board). Statutes do not prohibit the same individual from running for office each year, or from holding consecutive three-year terms ad infinitum. Not only do they not limit terms of office, they do not mandate that shareholders control the nominating process. They also do not restrict the use of dual class (non voting or lesser-voting) stock, which is a mechanism for undermining public shareholders' ability to elect

* Professor of Law, Yale Law School and School of Organization and Management. I would like to thank Peter Cramton, Henry Hansmann, Saul Levmore, Jon Macey, Alan Schwartz and Jeff Strnad for helpful comments and suggestions.

I. Bernard Black made a similar point in his excellent comment presented at this symposium. Black, Is Corporate Law Trivial?: A Political and Economic Analysis (forthcoming 84 Nw. U.L. Rev. (1990)). It should be evident that the desirability of not deviating from mandatory laws refers to the preference of shareholders, not managers. Without question, some managers might want to opt out of rules that shareholders favor (such as the duty of loyalty), and these rules may alter managers' behavior.

2. Gordon, The Mandatory Structure of Corporate Law, 89 Colum. L. Rev. 1549, 1553 n. 16 (1989). 
the board. Moreover, if we accept Gordon's description of rationally apathetic shareholders who always vote with management, ${ }^{3}$ then the intent of the provision, protecting the right of shareholders to select the members of the board, is itself suspect.

(ii) Boards of directors may not delegate to committees the decision to approve a merger. Courts routinely rely on the approval of a subset of directors - the disinterested/outsider directors-rather than the majority of the entire board in reviewing the validity of acquisitive transactions.

(iii) Dividend payouts are limited by statute. It is quite simple to circumvent these statutes and pay a dividend. ${ }^{4}$ Moreover, if a state has a particular payout restriction, such as a capital surplus requirement, which prevents a firm from paying out a dividend, it can reincorporate in a state that does not have the same rule.

(iv) Shareholder demand is required for derivative suits. Courts permit demand to be excused if "futile."

(v) Charter amendments require a majority shareholder vote. Firms may increase this requirement. For example, antitakeover charter provisions typically are locked in by a provision requiring a supermajority vote for modification or repeal. In addition, management can draft a short, clean charter and put important provisions into the corporate bylaws, where amendments do not require shareholder approval.

(vi) Shareholders must vote on certain mergers. The ability to choose the transaction's form makes this rule completely optional. As the Time-Warner-Paramount takeover battle makes plain, a corporation can schedule the required shareholder vote for a merger and then circumvent it by a simple change in the structure of the deal. ${ }^{5}$ (vii) Shareholders have appraisal rights to obtain the fair value of their shares instead of the consideration provided in certain mergers. The right is limited to the owner of record, as opposed to the beneficial owner, and subject to many technicalities for perfection. More important, the firm can avoid the exercise of appraisal rights by manipulating the structure of acquisitive transactions. ${ }^{6}$

(viii) Shareholders have the right to obtain the stockholders' list and to inspect books and records. Access is denied if the shareholder does not have a proper purpose, a qualification often broadly construed by courts, especially when the demand concerns access to the stockholders' list. ${ }^{\text {. }}$.

3. Id. at 1575-76.

4. For a demonstration of the statutes' limitations see B. Manning, A Concise Textbook on Legal Capital (I981).

5. Paramount Communs., Inc. v. Time, Inc., 1989 Del. Ch. Lexis 77, Fed. Sec. L. Rep. (CCH) \ 94,514 (1989).

6. E.g., Hariton v. Arco Elecs., 41 Del. Ch. 74, 188 A.2d 123 (1963).

7. E.g., Fleisher Dev. Corp. v. Home Owners Warranty Corp., 647 F. Supp. 661, 
(ix) Directors' actions are subject to derivative suits for breach of the duty of care and loyalty. The Delaware code section to which Gordon refers, section 102(b)(7), permits shareholders to eliminate directors' liability for breaches of the duty of care. Moreover, courts permit derivative suits to be terminated by the decision of special board committees. Finally, certain self-dealing transactions implicated by the duty of loyalty can be approved by disinterested directors.

The history of corporation codes suggests that when a mandatory rule's constraint becomes binding (that is, when a sufficient number of firms desire to deviate from the rule), then the code is invariably revamped in the direction of less restrictive (more optional) terms. For instance, voting requirements for mergers have been reduced from unanimity to majority rules, prohibitions on self-interested transactions have been lifted, preemptive rights are no longer required and firms may eliminate their directors' liability to shareholders for monetary damages for negligence. ${ }^{8}$ Even when states have restricted the actions of takeover bidders, the provisions have opt-out features. ${ }^{9}$ The steady movement toward enabling code provisions should give one pause before declaring any specific provision unalterable.

In fact, the rules that commentators most strongly insist should be mandatory are actually voluntary, in the sense that corporations would adopt them were they not already required. For example, consider a mandatory provision that is frequently invoked as an illustration of why corporate law should not be fully enabling: the duty of loyalty. Critics of enabling regimes suppose that shareholders would vote to permit managers to steal corporate, assets by rescinding the duty of loyalty. This is said to demonstrate a need for mandatory rules. But the hypothetical, eliminating the duty of loyalty, is too incredible to be seriously entertained: what sane shareholders would agree to license theft? Promoters have no incentive to include such a provision in a charter when a firm goes public, because investors would pay little, if anything, for the shares as the residual claim would be worthless. It is also unlikely to appear as a midstream amendment: even the least-sophisticated investor understands the catastrophic consequences of such a provision. If investors are so poorly informed or foolish to vote to transfer their

668-69 (D.D.C. 1986), aff'd, 856 F.2d 1529 (D.C. Cir. 1988); State ex rel. Pillsbury v. Honeywell, lnc., 291 Minn. 322, 329-31, 191 N.W.2d 406, 411 (1971).

8. An index of the demand side push by which a mandatory provision becomes enabling is the proportion of firms that have conformed their charters to Delaware's limited liability provision and the speed with which they acted: in examining a random sample of 170 Delaware firms, which was constructed for another research project, $94 \%$ of the 80 NYSE firms and $80 \%$ of the 90 OTC firms adopted such an amendment within one year of the statute's enactment. R. Romano, The Dynamics of Shareholder Litigation: An Empirical Study (1989) (unpublished manuscript).

9. One state's takeover statute does not include a specification of how firms may opt out of the provision's coverage. See New Jersey Shareholders Protection Act, N.J. Stat. Ann. $\S 14$ A:10A-1 to -6 (West 1989). 
wealth to managers without compensation, we have far deeper problems than refining corporation codes. How can we have confidence that investors will intelligently make the fundamental allocative investment decisions required in a capitalist economy? Or better yet, to participate in a democracy?

The hypothetical just proves too much. It is a paradigmatic example of a nonbinding mandatory rule, a rule from which no firm's shareholders would wish to deviate. In the rule's absence, firms' fiduciary restrictions concerning self-interested transactions would be homologous with current law. Such provisions are hardly mandatory as that term is commonly used: they are laws without bite.

The more important questions, in my opinion, are not whether we can find mandatory provisions in corporation codes to maintain that corporate law is or is not enabling or contractual, but rather ( 1 ) whether particular corporation code provisions maximize equity share prices; ${ }^{10}$ (2) whether the disequilibrium period during which a rule shifts from mandatory to enabling is so protracted as to impose substantial costs on investors; and (3) whether changing particular rules will create problems of the second best. ${ }^{11}$ By focusing on whether or not to attach a talismanic mandatory label to code provisions, the symposium avoids grappling with these core questions.

10. The evidence Gordon assembles provides little substantiation of other goals besides shareholder wealth maximization. He states that the rules relating to shareholder suits that internalize costs are intended to further the interests of third parties. To the contrary, they are directed to the shareholders' collective action problem, in protecting against frivolous suits and, at the same time, the free rider problem. Similarly, rules on board structure are directed to mitigating the principal-agent problem of the public corporation; the goal is not to internalize the cost of legal compliance. Gordon's historical claims are also unsubstantiated. The chartering of corporations to provide public goods in an earlier era does not indicate that the objective was not shareholder wealth maximization. The rate of return on those investments was not fixed by the state, as it is today for public utilities. Finally, it is difficult to locate a continuation of populist concerns in current codes. The most significant divergent feature from shareholder wealth maximization in state codes is the latest round of antitakeover statutes that permit boards to consider the interests of workers and communities as well as those of shareholders. See, e.g., Act approved June 29, 1989, ch. 1061989 N.J. Laws 106, § 1 (codified as amended at N.J. Stat. Ann. $\S 14$ A: 6-17) But, curiously, these groups are not given the right to enforce their inclusion in management's decisionmaking. There is a straightforward explanation for this phenomenon. The provisions are crafted principally to serve management's purposes, using ostensible concern for labor as a cynical tool to garner political support. The effect of the statutes is to make performance measurement exceedingly difficult, if not impossible, creating managerial rent-seeking opportunities. This is state codes advancing private wealth maximization with ruthless vengeance.

11. The theory of the second best holds that the solution for an unconstrained world (the first best) may no longer be efficient when real-world constraints, such as market imperfections, are added to the analysis. Lipsey \& Lancaster, The General Theory of Second Best, 24 Rev. Econ. Stud. 11 (1956). Accordingly, a single legislative reform that appears to be strictly welfare-improving can turn out to have the opposite effect. 


\section{Can Mandatory Corporate Laws Be Justified?}

\section{A. Justifications for Mandatory Rules}

Gordon introduces five justifications for mandatory corporate laws: investor protection, uncertainty, public good, innovation, and opportunistic amendment. He does not discuss a more conventional explanation for mandatory corporate law rules-transaction costs. By imposing contract uniformity, transaction costs are reduced because investors will not have to obtain and read a firm's charter before purchasing its securities. Of the explanations Gordon discusses, the transaction cost view is closest to what he terms the uncertainty hypothesis. The uncertainty hypothesis is more complex, though, for it maintains that even if shareholders can learn without cost a charter's distinctive content, they will still require mandatory terms because they cannot know for sure a distinctive provision's welfare consequences or how courts will give it effect.

Gordon criticizes both the uncertainty and investor protection hypotheses, and emphasizes instead the remaining three rationales, which are related by their characterization of the manager-shareholder relation as a prisoner's dilemma. I found the critique of the uncertainty and investor protection rationales compelling. I therefore will limit my remarks to the other three hypotheses.

1. The Public Good Hypothesis. - The public good justification for mandatory rules is premised on firms having an incentive to customize a standard form provision, which makes courts interpret deviations more frequently than the standard form, rendering uncertain the meaning of the standard form. ${ }^{12}$ This ostensible free-rider problem could, however, equally (if not more plausibly) cut in the opposite direction: firms may want not to customize their charters, but to free ride on the innovative efforts of others. There would then be a "suboptimal" rather than "superoptimal" level of charter deviations.

More important, it is unlikely that the payoff structure is the hypothesized prisoner's dilemma. While there is little evidence that deviations actually outnumber standard form contract provisions, there is even less evidence for the conclusion that decisions interpreting deviations blur the meaning of a standard form. Such decisions are unlikely to alter previous interpretations of the standard, and are more likely instead to sharpen our understanding of the standard form's contours. ${ }^{13}$

12. Gordon, supra note 2 , at 1567 . To the extent uncertainty over the legal consequence of charter provisions is the problem, the public good hypothesis collapses into the uncertainty hypothesis. This makes it equally subject to Gordon's critique of the latter hypothesis. See id. at 1566-67.

13. A paucity of litigation over the standard form in contrast to deviations may be evidence that the form is well understood and that few issues need to be adjudicated. It is also possible that the impetus for deviation is undesirable judicial interpretation of the standard form. 
Moreover, there is an alternative, and far more plausible, explanation of wide-scale deviation from a standard contract term. Suppose that clause $x$ is a standard form under a state corporation code. If firms routinely choose clause $y$ over clause $x$, then we know from their revealed preference of picking $y$ when they could have chosen $x$, that clause $x$ is suboptimal. It is then inconsistent to maintain, on efficiency grounds, that deviations (clause $y$ ) should be prohibited to preserve the clarity-that is, the utility-of the standard form (clause $x$ ). Clause $x$ should be abandoned, not propped up.

2. The Innovation Hypothesis. - The innovation justification for mandatory rules maintains that investors assume that a charter innovation proposed by management will be detrimental to their interest. Investors will accordingly undervalue shares in a corporation with an innovative charter and promoters will not propose beneficial innovations because by the time the market properly values the innovation ex post, it is the new owners (who bought at a low price), not the promoter (who sold at the low price), who reap the gains. State certification of innovation-by legislative shifts from mandatory to enabling provisions-is viewed as the only mechanism to mitigate this problem. This justification tracks both the investor protection and uncertainty hypotheses, for it assumes that shareholders are uninformed about the consequences of new charter provisions. It is accordingly subject to the same difficulties as those explanations.

The thesis is subject to two more serious weaknesses: (1) Why would (or should) shareholders assume that a firm's proposed charter innovation is at variance with their interest? ${ }^{14}$ and (2) why is state action necessary to certify the benefits of change? To entertain seriously the innovation justification, we need at least some theory and data for why the purchase of common stock is uniquely different from other consumer purchases: In the vast majority of product markets, firms innovate without state authorization and consumers do not have any difficulty determining whether an innovation is valuable. ${ }^{15}$. In fact, firms offer many devices, such as product warranties, to ensure product qual-

14. The relation between the innovation and opportunistic amendment hypotheses is puzzling, unless they are intended as alternative, rather than complementary, explanations. For the premise of the innovation hypothesis, that shareholders are suspicious of management's motives, is inconsistent with the premise of the opportunistic amendment hypothesis, that shareholders always approve management's proxy proposals.

15. Michael Trebilcock, Bruce Chapman and Ron Daniels, in their superb comment at this symposium on. Lucian Bebchuk's paper, also emphasize this problem. As they noted, one area in which the state restricts the introduction of product innovations, the FDA's regulation of new drugs, has, in fact, been widely criticized as unsuccessful in furthering consumers' interests. See Peltzman, An Evaluation of Consumer Protection Legislation: The 1962 Drug Amendments, 81 J. Pol. Econ. 1049, 1089 (1973). They therefore concluded, correctly in my view, that while the Peltzman study is controversial, it would be imprudent to promote state-controlled innovation without recognizing the problem the study raises of risk averse legislators. 
ity. Gordon provides little evidence for why the market for common stock-the most efficient market that we have-cannot do so as well.

Moreover, the promoter's problem Gordon describes more likely mitigates rather than creates a need for state intervention. A low price for a new issue is an important component of a private mechanism for ensuring the quality of innovation to outsiders: in an underpriced initial public offering, the proportion of shares the promoter retains is a signal of the quality of the issue, ${ }^{16}$ which we may interpret broadly to include both the business and organizational components. With statemandated innovation, the promoters' retained share is no longer an effective signal. This is likely to lower firm quality, as the outcome of this game will be a pooling rather than separating equilibrium.

If retained shares by management or other self-help remedies cannot reduce investors' uncertainty over the welfare effects of an innovative proposal, then there are incentives for private quality certification organizations, such as stock exchanges and underwriters, to do so. Of course, firms might prefer to have the state rather than private institutions warrant their quality under a rent-seeking explanation. The reason would be that the cost of state certification is defrayed by taxpayers rather than borne by the regulated firms. However, this is not a compelling scenario for corporation codes: the franchise tax places certification costs directly on the corporate beneficiaries.

The existence of a market failure in innovative charter terms is therefore unlikely. It is even more unlikely, however, that the political process would resolve the problem posed by the innovation hypothesis if private solutions did not. Shareholders who assume that managerial opportunism is the source of charter innovation have no reason to view legislative innovation more charitably. Corporation code reform is initiated by management and groups tied to it, such as chambers of commerce and the corporate bar, and not shareholder advocacy groups. ${ }^{17}$ Shareholders can, on average, treat the legislative process as a seal of quality assurance: Ralph Winter's position that state competition produces shareholder-wealth-maximizing laws has considerably greater

16. E. Rasmussen, Games and Information: An Introduction to Game Theory 218-19 (1989). To certify an innovation's welfare-enhancing properties, the promoter retains more shares. It is also possible for management to pay investors to accept innovation: they could provide a put option, that is, promise to redeem the shares at a particular price. I do not believe that such a practice has ever been used to certify charter innovation in the common stock new issue market. But the ability to make cash commitments, such as a put promise, resolves the adverse selection problem (the difficulty of distinguishing high and low quality firms). See Bhattacharya, Nondissipative Signaling Structures and Dividend Policy, 95 Q.J. Econ. 1 (1980). The availability of a self-help remedy-common stock put-in conjunction with its nonuse, suggests that the innovation justification is concerned with a pseudo-problem.

17. See Romano, The Political Economy of Takeover Statutes, 73 Va. L. Rev. 111, $122-41$ (1987). 
empirical support than William Cary's managerialist characterization. ${ }^{18}$ But the successive enactments of new generations of state takeover laws suggests that legislative innovation is certainly not always shareholder wealth enhancing. ${ }^{19}$ The number of shareholder wealth-reducing laws may be small, but a positive probability of such events diminishes the reliability of the signal of state certification when it matters most: innovations in end-game situations like corporate takeovers where management's conflict with shareholders is stark.

3. The Opportunistic Amendment Hypothesis. - The opportunistic amendment justification for mandatory rules is that such rules enable promoter-managers to precommit to investors that they will not propose charter amendments that reduce shareholder wealth (because they cannot change the rules ex post). I find this the most intriguing of Gordon's rationales for mandatory rules.

As a positive explanation of the mechanics of corporate law, I am, however, skeptical of its descriptive accuracy. The area in which management opportunism is considered rampant involves defensive tactics to hostile takeovers. Yet there are no mandatory laws preventing such activity. Not only can boards propose an unlimited variety of shark repellent charter amendments and take action without shareholder approval, such as adopting poison pills, selling prized assets, and acquiring other companies, ${ }^{20}$ but statutes also limit takeover activity. Given this enabling pattern, the opportunistic amendment hypothesis is a poor candidate for a positive theory. ${ }^{21}$

An additional problem of fit involves the assumption that sunk costs matter. A standard move for challenging economics' conventional marginal analysis that sunk costs do not matter is Oliver Williamson's idea of asset specificity, which refers to an asset that is more valuable in a particular transaction than in its next best use. ${ }^{22}$ But that concept is not applicable here. Gordon does not delineate

18. See Romano, Law as a Product: Some Pieces of the Incorporation Puzzle, 1 J.L. Econ. \& Org. 225, 267-73 (1985).

19. See Romano, supra note I7, at 122-41; Ryngaert \& Netter, Shareholder Wealth Effects of the Ohio Antitakeover Law, 4 J.L. Econ. \& Org. 373, 380-82 (1988); Schumann, State Regulation of Takeovers and Shareholder Wealth: The Case of New York's 1985 Takeover Statutes, I9 Rand J. Econ. 557, 566 (1988).

20. See, e.g., Moran v. Household Int'l, Inc., 500 A.2d 1346, 1353 (Del. 1985) (approving adoption of poison pill); Paramount Communs., Inc. v. Time, Inc., 1989 Del. Ch. Lexis 77, Fed. Sec. L. Rep. (CCH) q 94,514 (1989) (approving acquisition of companies); Capital City Assocs. Ltd. Partnership v. Interco Inc., 551 A.2d 787, 790-91 (Del. Ch. I988) (approving sale of assets).

21. The poor fit is not surprising to the extent that it makes most sense to select a mandatory rule for settled areas of law where the optimal practice is not in flux. The opportunistic amendment justification for a mandatory rule is, however, strongest for the case where organizational forms are in flux because shareholders are most vulnerable to exploitation when they cannot anticipate the consequences of management's action.

22. O. Williamson, The Economic Institutions of Capitalism (1985). 
how an investment in common stock is a transaction-specific asset. Others who have attempted to develop such an analysis emphasize the size of the holding: because large shareholders arguably cannot trade at the market price, their investment is said to be "transaction specific." 23 Large blocks of stock are not, however, the motor force of the opportunistic amendment hypothesis: it is driven by the actions of small shareholders, who are characterized as rationally apathetic voters.

Further, it is difficult to understand why Gordon refers to sunk costs in the first place when constructing the argument: the decline in stock price from a welfare-decreasing amendment is a real loss to shareholders, but it is hardly a sunk cost. Gordon does not appear to be maintaining that shareholders make substantial investments in searching corporate charter terms when they buy stock in an initial public offering, which would be a sunk cost they could not recoup upon selling their shares after a charter amendment. ${ }^{24}$ Moreover, there is no evidence that voting behavior is changed because shareholders have purchased their shares at a higher price under the original charter. The source of the loss in value is, rather, the shareholders' approval of an amendment that reduces future cash flows, and that depends on the rational apathy assumption (or an alternative assumption of coercion), not on the presence of sunk costs.

The characterization of shareholders as rationally apathetic-the linchpin of the opportunistic amendment hypothesis-is also highly problematic, for it involves strong and questionable assumptions concerning investor behavior. The crucial premise is that shareholders will consistently vote in support of management because of rational apathy. I have difficulty understanding why rationally apathetic voters are not just as likely to vote in the negative as in the affirmative: if there is any possibility of being exploited, why take a chance?25 Even more plausibly, why would they vote at all? In the political science literature from which the rational apathy story originates, rational apathy is used to explain why citizens do not vote, not why they vote a particular way. In the corporate law context, not voting can have a distinctive effect: if all uninformed shareholders abstain from voting, the firm will be either unlikely to meet a quorum requirement, or the votes of informed shareholders will dominate the outcome (so long as their votes outnumber management's).

Refraining from voting, however, is not necessarily an optimal strategy for the uninformed because management has two options if a

23. E.g., Baysinger \& Butler, Antitakeover Amendments, Managerial Entrenchment, and the Contractual Theory of the Firm, 71 Va. L. Rev. 1257, 1285-88 (1985).

24. E.g., Gordon, supra note 2, at 1557 n.26 (1933 Act disclosure requirements reduce research costs substantially).

25. Gordon presumes management offers a mix of both beneficial and opportunistic amendments. If management did not offer some beneficial amendments, then shareholders would have a dominant pure strategy-always vote against an amendment. 
quorum is not achieved: it can drop the proposal (the shareholders' preferred outcome), but it can also engage in costly resolicitation efforts. Yet, contrary to Gordon's contention, uninformed shareholders' dominant strategy is not, under these circumstances, always to vote yes. By adopting a strategy of voting yes only a proportion of the time, they can tilt the election toward the informed. Furthermore, this mixed strategy is optimal even if more beneficial amendments are proposed than opportunistic ones, so long as informed shareholders' interests are the same as the uninformed.

The advantage of a mixed strategy over Gordon's pure strategy of voting yes can be shown by the following simple illustration. Let insiders own $x$ percent of the shares, informed shareholders own $y$ percent, ${ }^{26}$ and uninformed own $z$ percent. To analyze the problem, some structure must be imposed on ownership. I make two plausible assumptions: (1) $x<y$ and (2) $x+y<q$ (where $q=$ quorum requirement), which imples that $x+y<z$. The first assumption is derived from empirical studies of ownership. ${ }^{27}$ The second gives some bite to the quorum requirement given the first assumption. ${ }^{28}$ Otherwise, the uninformed votes are not necessary for the election, as the informed constitute a quorum. When (1) holds $(x<y)$ but (2) does not $(x+y\rangle$ $q)$, then the uninformed have a dominant strategy to refrain from voting. This strategy ensures both that all beneficial amendments are adopted (all votes, $x+y$, are yes's and there are no no's) and that all opportunistic amendments are rejected (no's outnumber yes's, since $y$ $>x){ }^{29}$

Some proportion of the $n$ amendments that management offers, say $p$, are opportunistic, where, following Gordon, $p<(1-p) .^{30}$ Both

26. These shareholders are generally institutional investors who own large blocks of stock, and stock in many companies; becoming informed about proposals is not costly for them.

27. Institutions own, on average, approximately $40 \%$ of common stock. Office of the Chief Economist, Securities and Exchange Commission, Institutional Ownership, Tender Offers, and Long-Term Investments 6 (Apr. 19, 1985) (showing increasing trend, up to $38 \%$ in 1983). Insiders average from $2 \%$ for the largest corporations, to $20 \%$ for large to middle-sized corporations, to over $30 \%$ for smaller public corporations. Demsetz, The Structure of Ownership and the Theory of the Firm, 26 J.L. \& Econ. 375, 388 (1983) (table 1). As discussed infra note 34, the optimal strategy for the uninformed can still be a mixed strategy even if $x>y$ and $x+y>z$.

28. Quorum requirements are less than a majority. See, e.g., Del. Code Ann. tit. 8, $\$ 216$ (1983 \& Supp. 1988). If $x+y<.5$, then $x+y<z$ because $x+y+z=1$.

29. If (1) does not hold and $x>y$, then the uninformed votes are not necessary for the adoption of beneficial amendments since, again, all votes, $x+y$, are yes's. They must vote, however, and they must vote no, if there is to be any possibility of an opportunistic amendment being defeated. See infra note 34 .

30. Rather than use the complex notation of probability distributions, I assume a binomial distribution of $p$ and $(1-p)$. To simplify notation further, I assume the value to the outside shareholders of a beneficial amendment is +1 and the value of an opportunistic amendment is -1 ; this allows me to use the simple probabilities, rather than expected values, for the computations. 
management and the informed know an amendment's type. The uninformed, in contrast, know there is a positive probability of an opportunistic amendment, and they may even know $p$, but unlike management and the informed, they cannot distinguish among the $n$ proposals (their information set is coarser). In selecting a voting strategy, the uninformed want to maximize the probability of the $p n$ opportunistic amendments failing and the $(1-p) n$ beneficial amendments passing. They can follow three strategies: the pure strategy of always vote yes, the pure strategy of always vote no, and a mixed strategy of voting yes and no at random. ${ }^{31}$

If the uninformed vote no $p$ percent of the time, ${ }^{32}$ then for beneficial amendments the votes in favor will be $x+y+(\mathrm{I}-p) z$ with $p z$ opposed, and for opportunistic amendments, the votes in favor will be $x$ $+(1-p) z$ with $y+p z$ opposed. To be sure, both types of amendments obtain fewer yes votes than the outcome from Gordon's pure strategy of always vote yes. But this does not affect the adoption of beneficial amendments because there are still more yes than no votes, that is, (1$p) z>p z$. The fate of the opportunistic amendments is, obviously, of greater interest. If the uninformed always vote yes, because $z>x+y$, all such amendments are adopted. ${ }^{33}$ By adopting a random strategy, opportunistic proposals will be defeated if $(1-p) z-p z<y-x$. When the difference in the holdings of the informed and the insiders is large, an opportunistic amendment will be defeated if $p$ is sufficiently large. If we take average ownership holdings for the largest firms, the amendment will be defeated if $p>.2 .^{34}$ Therefore, the uninformed can benefit not

31. We have ruled out refraining from voting because of the need for a quorum. Refraining from voting could be included as an option in the mixed strategy; I do not do so because the greater complexity provides little in additional insight.

32. Each shareholder fills an urn with $p$ red marbles and (1-p) green marbles and picks a marble before voting each of her shares. If the chosen marble is green she votes the share yes, if it is red she votes no. The marble is then replaced in the urn and the process repeated for each share. Because each draw from the urn is independent, in the aggregate $p z$ percent of the uninformed shares will be voted no and $(1-p) z$ shares will be voted yes. The use of such a strategy is not that far-fetched. It is equivalent to there being two types of uninformed shareholders: $p$ percent who always vote no and $(1-p)$ percent who always vote yes.

33. The uninformed cannot all vote no to all amendments. That strategy would not only ensure the defeat of all opportunistic proposals but it would also ensure the defeat of all beneficial amendments as well, because $z>x+y$.

34. See supra note 27 , indicating average values for large corporations of $y=.38$ and $x=. .02$, which makes $z=.6$. When the insiders' holdings are large compared to the informed, opportunistic amendments will pass even under this strategy, as is the case of companies proposing dual class stock recapitalizations, where insiders own a high proportion and institutions a low proportion of the common stock. See Jarrell \& Poulsen, Dual-Class Recapitalizations as Antitakeover Mechanisms: The Recent Evidence, $20 \mathrm{~J}$. Fin. Econ. 129 (1988). Using their data $(x=.366$ and $y=.25$, which violates assumptions (1) and (2) in the text), the uninformed would have to fix the value of $p$ at greater than the objective frequency of an opportunistic amendment to meet the condition in the text for defeating an opportunistic amendment. They must choose $p>.558$, which 
only by employing a random strategy but from "overestimating" $p$ : so long as $p<(1-p)$, all beneficial amendments pass, yet using a $p$ that is higher than its objective frequency will ensure that an opportunistic amendment is defeated.

While tedious, the example makes plain that the optimal strategy for the rationally apathetic shareholder is not always to vote yes. Uninformed shareholders can do better with a mixed strategy. The opportunistic amendment justification for mandatory rules is, however, d́ependent upon their yes votes. If rationally apathetic shareholders are not better off voting yes all of the time, then the precommitment justification for mandatory rules is weakened: ex post opportunism is not inevitable if shareholders will not go along. lnsiders and public investors are concerued about ex post opportunism at the initial chartering stage only if the dominant strategy of shareholders is to vote yes to all amendments, so that opportunistic proposals are bound to pass. The exercise shows that this will be true only if there are no informed shareholders. Given the extent of institutional holdings, that scenario is highly unlikely. ${ }^{35}$

The implausibility of large numbers of uninformed shareholders always approving management's proposals is also evident in the context in which Gordon suggests the opportunistic amendment hypothesis will weigh most heavily: midstream charter amendments during a control battle. ${ }^{36}$ Shareholders are least likely to be rationally apathetic and therefore uninformed in this context, for their attention is focused by the bid premium. ${ }^{37}$ Moreover, the number of both well-informed shareholders and noninsider large blockholders will be higher than usual as arbitrageurs acquire shares. This is also a context in which the efficacy of state-mandated remedies is most questionable. For many of the most recent state takeover laws are adopted at the behest of a spe-

means $p>(1-p)$. Adopting such a strategy (voting no more frequently than yes) is optimal because it will not affect the outcome of any beneficial amendments for such a firm since $x+y>z$. However, a mixed strategy will not work if $x$ is so large and $y$ so small that $p$ must equal (or be greater than) 1 .

35. Even if there are no informed nonmanagement shareholders, the case for mandatory rules is still weak under Gordon's assumption that most amendments are beneficial rather than opportunistic. To continue to justify mandatory rules in these circumstances we must assume that the legislature can distinguish between good and bad amendments. However, since to get this far we must assume with Gordon that shareholders are not informed about an amendment's effect, it is equally unlikely that legislators, who have no personal financial stake, can make an informed judgment. Legislators need to be educated about issues, W. Muir, Legislature: California's School for Politics xii (1982), and they will hear only from management because shareholders, being rationally apathetic, will not be in a position to inform them. Again, the analysis promoting mandatory rules in the context of rational apathy fails.

36. See Gordon, supra note 2 , at $1577-80$.

37. For example, in a recent takeover bid, Time management so feared a shareholder vote on its proposed merger with Warner that it restructured the deal to avoid the vote, at a substantial cost to its shareholders. 
cific domestic company seeking to thwart a hostile bid, and take the form more of an opportunistic amendment than of a precommitment mechanism preventing such behavior. ${ }^{38}$

A final problem for the rational apathy story is that it overlooks learning across firms by investors. It thereby greatly overstates the cost of becoming informed. Firms imitate-conforming their charters to provisions of other firms-which enables investors to spread information costs across securities in their portfolios. In addition, institutional investors are organized and disseminate information on issues across firms. ${ }^{39}$ Further, stock prices convey substantial information concerning the thinking of informed investors on a proposal. As a consequence, uninformed investors can glean information on how to vote from price movements during the period from the announcement of a proposed amendment up through the shareholders' meeting. ${ }^{40}$ Given all the conceptual difficulties, it would be injudicious to ground corporate law in the rational apathy/vote yes assumption.

Gordon does suggest, alternatively, that in some instances shareholders may be informed about the adverse consequences of an amendment but are compelled to go along because of management's strategic use of the proxy apparatus. ${ }^{41}$ While I view this as a more plausible explanation than rational apathy, ${ }^{42}$ the theoretical problem may not be of much practical concern. Management's ability to manipulate the agenda to produce its preferred outcome is not possible if preferences are single-peaked, such that there is a true majority winner (the majority-preferred set consists of a single point). This is likely to be the situ-

38. E.g., Butler, Corporation-Specific Anti-Takeover Statutes and the Market for Corporate Charters, 1988 Wis. L. Rev. 365 (1988).

39. E.g., Sontag, A Takeover Law Grows in Delaware, Nat'l L.J., Apr. 11, 1988, at 1 (describing efforts of T. Boone Pickens' lobbying group, United Shareholders Association); Institutional Investors Join Forces for Clout, Wash. Post, May 12, 1985, at F1.

40. If the uninformed shareholders' interest is not the same as that of the informed, as long as they understand the difference, share prices will still provide the requisite information. See generally McKelvey \& Ordeshook, Information, Electoral Equilibria, and the Democratic Ideal, $48 \mathrm{~J}$. Pol. 909 (1986) (uninformed voters in general elections can infer from the preferences of the informed how they should vote). In fact, one explanation of the empirical evidence of shareholder approval of shark repellent amendments despite large stock price declines is that the interest of uninformed investors (individuals holding few shares) and informed investors (institutions holding larger blocks) diverge with respect to the amendments. Romano, supra note 17 . It is, in any event, contradictory to maintain that shareholders always vote with management but that stock prices will not decline on the announcement of an opportunistic proposal because informed investors will not assume that the proposal will be approved. Rather, if shareholders always vote with management, so that its proposals are always adopted, informed investors would discount their votes and act accordingly.

41. Gordon, supra note 2, at 1577-78.

42. See Romano, The State Competition Debate in Corporate Law, 8 Cardozo L. Rev. 709, 755 (1987) (management control of the agenda as problem for informed shareholders). 
ation in most large corporations, because the public shareholders' preferences will be single-peaked (they invest to make more money).

Moreover, Gordon's illustrations of strategic management behavior provide questionable evidence of coercion. Shareholders who approve dual class stock recapitalizations typically receive a higher share of the firm's earnings in exchange for a lesser share of voting rights. Gordon views consent to such an exchange as an instance of coercion, because the "sweetener" of stock with higher dividends induces shareholders to reduce their wealth by giving up stock with voting rights. This exchange can, however, be reasonably characterized as strictly welfare improving. In the recapitalizing firms, the insiders already have voting control (averaging approximately forty percent), ${ }^{43}$ so the value of voting rights for the public shareholders-the opportunity to control the firm or to receive a premium in a control change-is minimal. Under such circumstances, it is doubtful that outsiders ever placed much value on voting rights. In this regard, receipt of a higher cash flow in exchange for voting rights that were illusory to begin with is a welfare-enhancing, and not strategically coercive, transaction.

I am also not convinced that a dual class stock recapitalization is a game of chicken that insiders win. Management's threat to decrease the value of the firm if the recapitalization is not approved is not credible. There is an alternative mechanism for raising capital without diluting the insiders' control or risking bankrnptcy-a preferred stock issue-and no tangible way for management to precommit to destroy firm value if the recapitalization is not approved. So long as that option is available, because more of the insiders' than the public's wealth is tied to the firm, the public is in an excellent position to call management's bluff. In the absence of a formal model of the game which identifies an equilibrium, ${ }^{44}$ it is impossible to conclude that these recapitalizations are coercive rather than efficient exchanges.

Finally, management's ability to bundle beneficial and opportunistic proposals is limited. No doubt clever drafting of "add-ons" aids management. But most proposals of charter amendments are separately placed on the agenda, requiring separate votes. To avoid separate votes, management has to reincorporate. ${ }^{45}$ Because a reincorporation is more costly than a charter amendment, this strategy is not likely to be repeated often.

There is a further general difficulty with justifying mandatory rules from any of the illustrations-selection bias. The standard course of a

43. Jarrell \& Poulsen, supra note 34 .

44. My concern is that management's threat violates the requirement of subgame perfection. The chicken game Gordon describes is appropriate only for a simultaneous move game, whereas the recapitalization game is a sequential game.

45. Although management must disclose the differences, the terms of the new firm's charter are not separately approved in a reincorporation; rather, the shareholders vote only on the entire transaction. 
charter amendment involves management hiring a proxy solicitation firm, which advises it concerning the likelihood of shareholder approval. Management then offers up only those provisions that are likely to be adopted. This makes it problematic to infer coercion from uniform consent: we would need information on the universe of all firms and potential amendments to reach such a conclusion.

\section{B. The Appraisal Rights Alternative to Mandatory Rules}

As Bengt Holmstrom suggested in his symposium remarks, it is possible that shareholders' wealth will be greater if managers can commit-because of the law-to retaining ex ante efficient charter amendments than if, in the absence of commitment, shareholders must engage in costly monitoring. While Gordon does not state his thesis quite this way, he does seek to buttress the opportunistic amendment justification of mandatory rules by considering-and rejecting-alternative monitoring regimes: appraisal rights for amendments, supermajority voting rules and fair adoption tests. I am not persuaded that the cost of supporting precommitment through mandatory corporate law rules is less than the cost of at least one of the alternative policing regimes, appraisal rights for charter amendments. ${ }^{46}$

Gordon finds the use of appraisal rights unappealing because it may be difficult to value the loss caused by a charter amendment. The difficulty in valuation is overstated. First, single firm betas are not the problem that Gordon suggests; as is typically done in capital budgeting, industry betas can be used for estimation. ${ }^{77}$ The fact that firms in an industry are subject to similar trends, such as takeover activity, is not a problem: if every other firm in an industry has already adopted the amendment at issue, there would still be a price reaction for the firm in question. This is because its price would be higher compared to the industry before the amendment is adopted, and it would hence experience a significant decline-to the industry level-that other firms would not experience at that time. ${ }^{48}$ Moreover, if the robustness of a single firm regression is of concern, we can make probative the stock price effects of a portfolio of firms adopting the amendment.

Second, changes in corporate structure are priced..$^{4}$ if a loss in

46. To the extent that the concern over opportunism is, as Gordon suggests, a concern about uncompensated transfers (Kaldor-Hicks efficiency), then the appropriate response should be a compensated wealth transfer. An appraisal process precisely fits this function. 1988).

47. See R. Brealey \& S. Myers, Principles of Corporate Finance 181-84 (3d ed.

48. An extremely strong rational expectations view would maintain that after the first firm in an industry adopts such an amendment, investors anticipate all other firms' imitation and all stock prices experience the full negative effect of the amendment at that earlier date. The court would then need to examine price effects at that earlier date and not simply at the imitator's adoption date.

49. See Jarrell, Brickley \& Netter, The Market for Corporate Control: The Empiri- 
stock value upon a charter amendment cannot be identified even crudely, then the more plausible policy conclusion is that the presumption that the proposal is opportunistic should be rejected. If the fear is that management may introduce a confounding event to counteract an amendment's negative stock price effect, the court can permit shareholders to produce data on stock price reactions to the two disparate events from the voluminous finance literature, to aid in sorting out the effects. Moreover, given its control over corporate events, the burden of proof can be placed on management. For instance, there can be a presumption of a negative stock price effect whenever there are managerially controllable confounding events. Or, there can be a presumption that an unexplained negative stock price effect prior to the announcement of the proposed amendment is due to management's leaking of the proposal. As outcomes often turn on who bears the burden of proof, this technique sbould mitigate the impact of strategic management behavior.

True, the valuation exercise is imprecise and requires judgment. The real issue is whether its inaccuracy is more costly than mandatory substantive laws. Given this criterion, appraisal is a superior alternative. A mandatory regime is more likely to over or under compensate shareholders than an optional regime with appraisal rights for dissenters, because of the windfalls and wealth transfers created when specified behavior is prohibited or particular restrictions are relaxed by the legislature midstream. The benchmark for appraisal, the stock market, is a much finer gauge of value than even the most conscientious state legislature.

Gordon's final criticism of appraisal rights, that the possibility of overcompensation will encourage frivolous proceedings (objections to beneficial amendments) and tbereby threaten the "cohesiveness" of firms, is, in my judgment, not well founded. This is because it is at odds with many of Gordon's otber assumptions: if we assume with Gordon both that the cost to any shareholder of appraisal is high (the collective action problem) and that the difficulty of sbowing a decrease in value is great, then it is questionable that a shareholder will bring a nuisance suit (or be able to extract a settlement from such a threat). However, to make sure the exercise of appraisal rights is not an empty remedy, subject to the free rider problem tbat produces rationally apathetic voters, the proceeding's costs would have to be borne by the firm rather than the investor (which often occurs in practice but is not required). Such a policy might exacerbate Gordon's concern about frivolous proceedings.

Institutional safeguards would therefore have to be devised to min-

cal Evidence Since 1980, 2 J. Econ. Persp. 49 (1988); Symposium on Corporate Governance, $20 \mathrm{~J}$. Fin. Econ. (1988). 
imize potential nuisance suits.50 One such device would be to require a minimum number of shareholders to exercise their appraisal rights before the process can be invoked for a charter amendment, on the view that a dissenting numbers test is a proxy for adverse impact. Having more shareholders sue would increase the possibility of a "cash drain," which might make the firm draw back from its chosen course. But this is the very objective of the remedy-to deter value-decreasing amendments that shareholders would disapprove.

While the number of charter amendments would be reduced with an appraisal regime, it is more likely that the reduction will disproportionately affect opportunistic, rather than beneficial, amendments. This is because informed investors will not dissent to beneficial amendments, for they will want to retain their shares and they know that they will not be able to prove a loss to benefit from the proceeding. There is also no reason to assume that there will be significantly fewer beneficial amendments under an appraisal system than under a system of substantive mandatory rules. For given Gordon's assumption that most amendment proposals are beneficial, if the set of mandatory laws is not very small, the legislature will itself mistakenly restrict the more numerous set of beneficial amendments. At least under an appraisal system, there is some indicia, the market price, of investors' beliefs about an amendment's effect on shareholder wealth.

\section{Conclusion}

Although Gordon sets out to offer a positive account of mandatory rules that follows the current state of Delaware corporation law, he slides prescriptions for courts and legislatures into the concluding section. We get an ought from a rather questionable is without a sustained explanation. None of the hypotheses stressed-public good, innovation, or opportunistic amendment-provides criteria for predicting ex ante the content of a mandatory rule, which is what we require of a positive theory. That also renders impossible the specification of normative implications.

The innovation hypothesis offers more in the nature of ex post explanation than prediction: a state decision to change a mandatory rule to an enabling one indicates that a beneficial innovation has been devised. It is unlikely, for instance, that any proponent of the innovation hypothesis in 1984 would have predicted that the duty of care would be made enabling. The public good hypothesis is also a weak predictor, for its reasoning supports a code consisting only of mandatory provisions, as all contract terms, no matter how "clearly" written, can end up

50. Since many states already permit appraisal rights for dissenters to charter amendments, it would be most appropriate to look at their experience first to determine if any protective procedures are necessary. See, e.g., N.Y. Bus. Corp. Law $\S 806(b)(6)$ (McKinney 1986). 
in court. The predictive content of the opportunistic amendment hypothesis is similarly imprecise. It appears to require prohibiting charter changes by legislative act (repealing the standard reservation of powers clause) because the power to alter codes and make conforming charter changes attenuates the usefullness of a mandatory code as a precommitment device. We would have to merge the opportunistic amendment justification with the innovation justification, despite their contradictory views of shareholder behavior, for mandatory rules to serve as a credible commitment. If, however, we do so and view the hypothesis as permitting charter reform by statutory amendment, then it merely reinforces the influence of state competition in instructing legislators to consider their reputation with investors before removing a mandatory provision.

Gordon provides several proposals-legislatures (or courts) should (1) not permit opting out of fiduciary duties, (2) retain some mandatory content in corporate law, and (3) draft enabling statutes in the form of opt-in rather than opt-out provisions. In fact, while some of the proposals are sensible, ${ }^{51}$ none flows easily from the three explanations for mandatory rules. Prohibiting the legislature from making any provision waivable runs counter to the core of the innovation hypothesis, because the hypothesis takes legislative change at face value as an indicia of the shareholders' interest. Permitting enabling statutes in the takeover context is at odds with the key assumption of the opportunistic amendment hypothesis-shareholder rational apathy (or the subsidiary assumption of coercion). If shareholders always vote with management, an opting-in provision will not affect the content of the charter. It therefore diminishes the value of the precommitment device obtained by mandated state action in the first place, because management can offer up subsequent charter amendments that the legislature approves. Without a precise statement of the conditions under which we can characterize specific legislation as a wealth-maximizing certification of innovation or a rent-seeking wealth transfer, we cannot ascertain whether any provision, such as the duty of loyalty or a takeover defense, should be mandatory or optional.

While I have emphasized that we should be wary of positive claims and normative prescriptions for mandatory corporate law rules, there is, nonetheless, a role for mandatory corporate law when externalities are present. The important externalities, however, differ from Gordon's prisoner's dilemmas, and they can be mitigated only at the federal level. The analysis of the relevant externalities has been rehearsed in the literature, particularly with respect to state takeover statutes: because shareholders do not typically .reside in the legislating state but management and workers do, the state may not properly cali-

51. See Romano, supra note 42 , at 753-54 (advocating opt-in provisions when statutes change shareholder-manager relations and we can intuit conflicting interests, such as takeover statutes). 
brate the costs and benefits of a specific corporate statute. ${ }^{52}$. The national government, which includes all constituencies in its borders, will.

In this view, federal laws have a higher claim to being mandatory than state laws, as they are more likely to emerge from a political process that fully counts the costs and benefits to shareholders. This is, of course, not always the case: competition makes a legislature more responsive to the demands of the affected parties. ${ }^{53}$ The decisive question is whether there is an externality: is any third party's interest at stake that can subvert the beneficial operation of state competition and enable management to lobby successfully for laws not in the shareholders' interest?54 Even if we can identify a specific externality, there is still a further question to resolve before advocating a mandatory national law: will the outcome of the political process be better or worse than the market failure it seeks to cure?

I have maintained elsewhere that Congress's ability to internalize externalities in corporate law is, at times, questionable. ${ }^{55}$ But notwithstanding the considerable difficulties with congressional politics, if we are to locate a meaningful mandatory corporate law discussion, it is with regard to national and not state laws.

52. E.g., Romano, Future of Hostile Takeovers: Legislation and Public Opinion, 57 U. Cin. L. Rev. 457, 65-68 (1988).

53. See, e.g., Easterbrook \& Fischel, Voting in Corporate Law, 26 J.L. \& Econ. 395, 427 (1983) (state laws have a better claim to shareholder wealth maximization than federal laws because of competition).

54. This is a view of state opportunism against the firm, or of manager opportunism at the legisltive lobbying level and not at the firm level of a charter amendment, which is quite different from the opportunism with which Gordon is occupied. The state is the problem and not the solution in this analysis. See generally Grandy, Can Government Be Trusted to Keep Its Part of a Social Contract?: New Jersey and the Railroads, 1825-1888, 5 J.L. Econ. \& Org. 249 (forthcoming 1989) (discussing severe opportunism problem when the state is both party to and enforcer of a contract).

55. Romano, Future of Hostile Takeovers, supra note 52. 